\title{
MUTU IKAN ROA (Hemirhamphus sp.) ASAP YANG ADA DI PASAR TRADISIONAL DI KOTA MANADO YANG DISIMPAN PADA SUHU RUANG
}

\author{
Chlara Noni Patty ${ }^{1}$, Verly Dotulong ${ }^{2}$ dan I Ketut Suwetja ${ }^{2}$ \\ 1) Mahasiswa pada Program Studi Teknologi Hasil Perikanan FPIK Unsrat Manado \\ 2) Staf pengajar pada Program Studi Teknologi Hasil Perikanan FPIK Unsrat Manado \\ Email: chlara_patty@yahoo.co.id
}

\begin{abstract}
Fish is a source of food that is needed by humans because it contains a lot of protein. Protein and water contained in fish is quite high, so the fish including perishable commodities. Therefore, it is necessary to inhibit the process of decay by means of preservation and processing. Fumigation is one of the ways of fish processing that works to preserve and provide aroma with a distinctive flavor. Curing fish intended to have lasting power and gives a distinctive aroma. Roa fish or halfbeak (Hemiramphus sp.) Smoke (traditional name is Galavea) is one of the processed fish products consumed by the people who processed traditionally done by generations in North Sulawesi. Roa smoked fish processing business is done today is done with a simple technique using wood as fuel. This study aims to determine the quality of fish roa Fumes that are sold in traditional markets in the city of Manado through a test moisture content, Total Volatile Base Nitrogen (TVB-N), Total Plate Count (TPC), pH and Organoleptik during $0,7,14$ and 21 days of storage at room temperature. The method used is descriptive exploratory method which collects data fact that has been available in the field through the records and observations in detail and then systematically analyzed data based on quantitative and qualitative data. The parameters used in this study is a test moisture content, $\mathrm{pH}, \mathrm{TVB}-\mathrm{N}, \mathrm{TPC}$ and Appearance. With the results obtained from the analysis of the highest water content (14.4), the lowest (12.1); The highest $\mathrm{pH}$ test (6.75), the lowest (5.87); TVB-N test the highest (63), the lowest (41.58); The highest TPC test $\left(39.5 \times 10^{3}\right)$, the lowest $\left(13 \times 10^{2}\right)$; organoleptic highest appearance (7.4), the lowest (5.3); The highest odor organoleptic (7.9), the lowest (6.5); organoleptic taste of the highest (7.9), the lowest (6.9); organoleptic texture highest (7.5), the lowest (7.1).
\end{abstract}

\begin{tabular}{ll}
\hline Keyword: & $\begin{array}{l}\text { Fish halfbeak (Hemiramphus sp.), Quality of Fish, Water content, } p H, T V B-N, T P C, \\
\text { Appearance. }\end{array}$
\end{tabular}

Ikan merupakan salah satu sumber makanan yang sangat dibutuhkan oleh manusia karena banyak mengandung protein. Kandungan protein dan air yang terdapat pada ikan cukup tinggi, sehingga ikan termasuk komoditi yang mudah busuk. Oleh karena itu, diperlukan upaya untuk menghambat proses pembusukan dengan cara pengawetan dan pengolahan. Pengasapan adalah salah satu cara pengolahan ikan yang berfungsi untuk mengawetkan serta memberi aroma dengan cita rasa yang khas. Pengasapan ikan ditujukan untuk mendapatkan daya awet dan memberi aroma yang khas. Ikan Roa atau Julungjulung (Hemirhamphus sp.) asap (nama tradisionalnya adalah Galavea) adalah salah satu produk ikan olahan yang dikonsumsi oleh masyarakat yang diolah secara tradisional yang dilakukan secara turuntemurun di Sulawesi Utara. Usaha pengolahan ikan roa asap yang dilakukan saat ini masih dilakukan dengan teknik yang sederhana dengan menggunakan kayu sebagai bahan bakarnya. Penelitian ini bertujuan untuk mengetahui mutu ikan roa asap yang di jual di pasar tradisional di kota Manado melalui uji Kadar air, Total Volatile Base Nitrogen (TVB-N), Total Plate Count (TPC), pH dan Organoleptik selama 0 hari, 7 hari, 14 hari dan 21 hari penyimpanan pada suhu ruang. Metode penelitian yang digunakan adalah metode eksploratif deskriptif yaitu mengumpulkan data fakta yang telah tersedia dilapangan melalui pancatatan dan pengamatan secara terperinci dan sitematik kemudian dilakukan analisa data berdasarkan data kualitatif dan data kuantitatif. Parameter yang digunakan dalam penelitian ini adalah Uji Kadar air, pH, TVB-N, TPC dan Organoleptik. Dengan hasil yang diperoleh dari analisa kadar air tertinggi $(14,4)$, terendah $(12,1)$; uji $\mathrm{pH}$ tertinggi $(6,0)$, terendah $(5,87)$; uji TVB-N tertinggi (60.9), terendah $(43,26)$; uji TPC tertinggi $\left(39,5 \times 10^{3}\right)$, terendah $\left(13 \times 10^{2}\right)$; organoleptik kenampakan tertinggi $(7,4)$, terendah $(5,3)$; organoleptik bau tertinggi $(7,9)$, terendah $(6,5)$; organoleptik rasa tertinggi $(7,6)$, terendah $(6,9)$; organoleptik tekstur tertinggi $(7,5)$, terendah $(7,1)$.

Kata Kunci: Ikan Julung-julung (Hemirhamphus sp.), Kadar Air, pH, TVB-N, TPC, Organoleptik. 


\section{PENDAHULUAN}

Laut Indonesia merupakan sumber kekayaan alam yang melimpah dengan hasil yang beraneka ragam baik berupa produk hayati maupun non hayati. Ikan Ikan mengandung zat gizi utama berupa protein, lemak, vitamin dan mineral. Kandungan lemak dan protein yang terdapat pada daging ikan walaupun tinggi juga bervariasi antara ikan yang satu dengan yang lainnya.

Ikan juga merupakan salah satu sumber makanan yang sangat dibutuhkan oleh manusia karena banyak mengandung protein. Kandungan protein dan air yang terdapat pada ikan cukup tinggi, sehingga ikan termasuk komoditi yang mudah busuk. Oleh karena itu, diperlukan upaya untuk menghambat proses pembusukan dengan cara pengawetan dan pengolahan. Pengasapan adalah salah satu cara pengolahan ikan yang berfungsi untuk mengawetkan serta memberi aroma dengan cita rasa yang khas.

Pengasapan merupakan suatu cara pengolahan atau pengawetan dengan memanfaatkan kombinasi perlakuan pengeringan dan pemberian senyawa kimia dari hasil pembakaran bahan bakar alami (Wibowo, 2000). Selanjutnya dinyatakan bahwa pada dasarnya ada dua tujuan pengasapan ikan yaitu : pertama, untuk mendapatkan daya awet yang dihasilkan asap; dan kedua, untuk memberikan aroma yang khas tanpa memperdulikan kemampuan daya awetnya. Di Kota Manado ada beberapa jenis ikan yang dapat diolah dengan cara pengasapan, salah satunya ialah ikan roa atau julung-julung (Hemirhamphus sp). Adapun pemasarannya meliputi daerah Manado, Gorontalo, dan Palu (DKP Banggai, 2008).

Selama ini belum banyak penelitian tentang ikan ini, akan tetapi soal rasa sudah bukan menjadi rahasia lagi bahwa keistimewaan dapat dinikmati oleh masyarakat Indonesia bahkan mancanegara. Di Manado, ikan ini umumnya dipasarkan sudah diawetkan terlebih dahulu yaitu dengan cara pengasapan. Cara pengawetan ini untuk mengurangi kadar air tanpa menghilangkan nilai gizinya sehingga ikan dapat tahan lebih lama atau daya awetnya lebih panjang. Pengasapan ikan ditujukan untuk mendapatkan daya awet dan memberi aroma yang khas. Ikan Roa atau Julung-julung asap (nama tradisionalnya adalah Galavea) adalah salah satu produk ikan olahan yang dikonsumsi oleh masyarakat yang diolah secara tradisional yang dilakukan secara turun-temurun di
Sulawesi Utara. Usaha pengolahan ikan roa asap yang dilakukan saat ini masih dilakukan dengan teknik yang sederhana dengan menggunakan kayu sebagai bahan bakarnya. Ikan Roa (dalam bahasa inggrisnya Garfish) lebih dikenal berasal dari daerah Sulawesi Utara atau Manado dan sekitarnya, perairan pantai menjadi habitatnya dan umumnya terdistribusi di wilayah perairan Indo-Pasifik dan wilayah perairan Australia bagian utara. Dan merupakan salah satu jenis ikan ekonomis penting karena memiliki rasa yang gurih dan sangat diminati oleh pasar apalagi untuk produk ikan julung-julung/roa asap, sehingga harganya juga tetap stabil.

Ikan roa asap banyak dijual di pasarpasar di kota Manado, tetapi masih kurang data hasil penelitian tentang mutu ikan roa asap khususnya tentang TVB-N dan $\mathrm{pH}$. Oleh karena itu, penting untuk melakukan penelitian tentang mutu ikan roa asap di beberapa pasar yang ada di kota Manado.

\section{METODOLOGI PENELITIAN}

Metode penelitian yang digunakan adalah metode eksploratif deskriptif, yaitu mengumpulkan data fakta yang telah tersedia dilapangan melalui pancatatan dan pengamatan secara terperinci dan sitematik kemudian dilakukan analisa data berdasarkan data kualitatif dan data kuantitatif (Sudjana dan Kusuma, 2004).

\section{Tempat dan Waktu Penelitian}

Sampel ikan roa asap dibeli di pasar Karombasan. Pengukuran mutu ikan roa asap dilaksanakan di Laboratorium Pengendalian Mutu Hasil Perikanan, Fakultas Perikanan dan Ilmu Kelautan Universitas Sam Ratulangi Manado. Kegiatan penyusunan rencana kerja penelitian, pelaksanaan penelitian hingga penyusunan skripsi dilakukan kurang lebih 4 bulan mulai dari bulan April sampai dengan bulan Juli 2015.

\section{Bahan dan Alat}

Bahan yang digunakan dalam penelitian ini adalah ikan roa asap. Bahan yang digunakan untuk analisis TVB, yaitu TCA (Trikhloroacetic Acid) $7 \%$, larutan Kalium karbonat $\left(\mathrm{K}_{2} \mathrm{CO}_{3}\right)$ jenuh, TCA 7,5\%, Larutan Indikator (methil red dan bromo cresol green), Asam borat $\left(\mathrm{H}_{3} \mathrm{BO}_{3}\right)$, Asam klorida $(\mathrm{HCl} 0,02 \mathrm{~N})$, dan vaselin. Bahan yang digunakan untuk 
pengukuran nilai $\mathrm{pH}$ adalah larutan buffer $\mathrm{pH} 7$, akuades, dan kertas lakmus. Bahan yang digunakan untuk pengujian TPC, yaitu NA dan $\mathrm{NaCl}$.

Alat-alat yang digunakan untuk analisa kadar air, yaitu Cawan porselin, desikator, oven dan timbangan analitik. Alat-alat yang digunakan untuk analisa TVB, yaitu kertas whatman, cawan Conway, mortar, pipet, inkubator, mikro buret, gelas kimia, pipet tetes, corong kaca, spatula, dan kertas label. Alat-alat yang digunakan untuk pengukuran $\mathrm{pH}$ yaitu mortar, pH-meter, homogenizer, gelas kimia, dan $\mathrm{pH}$ indikator universal, kertas label. Alatalat yang digunakan untuk uji TPC, yaitu Cawan petri, Erlenmeyer, tabung reaksi, gelas ukur, magnetic stirrer, pipet pengenceran, gunting, pisau, lampu Bunsen, spatula, laminary flow, autoclave, oven, timbangan, botol semprot (alcohol), panic dan kompor. Alat-alat yang digunakan untuk uji organoleptik pulpen, score sheet (lembar penilaian).

\section{Perlakuan}

Perlakuan yang diterapkan dalam penelitian ini dirancang sebagai berikut: Ulangan yang digunakan dalam penelitian adalah sebanyak 2 kali.

(A). Lokasi pengambilan sampel

A1 = Pasar Karombasan

(B). Lama penyimpanan

$$
\begin{aligned}
& \mathrm{B} 1=0 \text { hari } \\
& \mathrm{B} 2=7 \text { hari } \\
& \mathrm{B} 3=14 \text { hari } \\
& \mathrm{B} 4=21 \text { hari }
\end{aligned}
$$

\section{Tata Laksana Penelitian} berikut:

Tata laksana penelitian adalah sebagai

- Ikan julung-julung asap dibeli di pasar yang ada di Kota Manado, yaitu Pasar Karombasan. Ikan dibeli dari 2 pedagang yang berbeda, satu pedagang dibeli sebanyak 120 ekor atau 6 gepe (1 gepe 20 ekor). Ikan kemudian dimasukan ke dalam kantong plastik untuk selanjutnya dibawa ke laboratorium untuk perlakuan selanjutnya. Selanjutnya ikan Roa Asap disimpan selama satu minggu atau 7 hari pada suhu ruang (27$\left.30^{\circ} \mathrm{C}\right)$.

- Analisa yang dilakukan meliputi Pengujian TPC (Total Plate Count), TVB-N dengan metode Conway, Kadar air menggunakan metode oven dan $\mathrm{pH}$ dengan menggunakan
pH meter. Sebelum pengujian TVB-N, pH dan Kadar air, daging ikan dihancurkan dengan menggunakan mortar, selanjutnya ditimbang sebanyak $10 \mathrm{~g}, 5 \mathrm{~g}, 10 \mathrm{~g}$ dan $5 \mathrm{~g}$, masing-masing untuk pengujian TPC, TVB$\mathrm{N}, \mathrm{pH}$ dan Kadar air. Pengujian dilakukan secara bersamaan untuk kelima parameter uji. Untuk pengujian Organoleptik dilakukan pengujian yang berbeda yaitu dengan menggunakan Score sheet (lembar penilaian) pada sampel utuh.

- Pengujian TPC, TVB-N, pH, kadar air, dan organoleptik sampel dilakukan dengan 2 kali ulangan untuk setiap perlakuan penyimpanan.

\section{Parameter yang Diamati dan Cara Pengujiannya \\ Analisa Kadar Air}

Menurut Sudarmadji, dkk (1989), kadar air ditentukan dengan menghitung kehilangan berat dari sampel yang dipanaskan. Prosedurnya adalah sebagai berikut:

- Cawan porselin dan penutupnya dibersihkan kemudian dikeringkan dan dioven pada suhu $105^{\circ}-110^{\circ} \mathrm{C}$ selama $1 \mathrm{jam}$, selanjutnya didinginkan dalam desikator selama 30 menit dan ditimbang beratnya (A).

- Sampel ditimbang sebanyak 2 g dalam cawan porselen yang sudah diketahui beratnya (B). Sampel dalam cawan porselin ini kemudian dikeringkan dalam oven pada suhu $105^{\circ}-$ $110^{\circ} \mathrm{C}$ selama 24 jam, selanjutnya didingankan dalam desikator selama 30 menit dan ditimbang $(\mathrm{C})$.

- Penimbangan ini dilakukan berulang-ulang sampai diperoleh berat yang konstan. Persentase kadar air dapat dihitung dengan rumus:

$$
\text { Kadar air }=\frac{(B-C)}{(B-A)} \times 100 \%
$$

\section{Analisa Total Volatile Base - Nitrogen (TVB- N)}

Menurut Suwetja (1993), analisa TVB$\mathrm{N}$ adalah sebagai berikut:

- Daging ikan ditimbang sebanyak 5g dengan menggunakan timbangan analitik, dihaluskan menggunakan mortar kemudian dihomogenkan dengan $10 \mathrm{ml}$ larutan TCA $7,5 \%$ di dalam mortar sampai sampel homogen. Kemudian sampel dipindahkan ke gelas beker terus didiamkan selama 30 menit. 
- Selama menunggu proses tersebut, permukaan badan cawan Conway beserta tutupnya diolesi vaselin secara merata untuk mencegah keluarnya basa-basa menguap dari dalam cawan tersebut.

- Sampel yang didiamkan tadi disaring dengan kertas whatman (no. 2-3) untuk mendapatkan ekstrak daging.

- Selanjutnya $1 \mathrm{ml}$ larutan Asam Borat (H3BO2), dan 2 tetes larutan indikator dipipetkan ke dalam cawan bagian dalam (inner chamber).

- Di pipet $1 \mathrm{ml}$ ekstrak daging kedalam cawan bagian luar (outer chamber), kemudian cawan ditutup dengan sedkit terbuka.

- Selanjutnya dipipetkan $1 \mathrm{ml}$ larutan Potassium Karbonat Jenuh $\left(\mathrm{K}_{2} \mathrm{CO}_{3}\right)$ ke dalam cawan bagian luar diisi yang bersebrangan dengan ekstrak daging kemudian ditutup rapat.

- Kemudian diputar-putar beberapa kali supaya larutan ekstraksi daging ikan dan larutan Potassium Karbonat $\left(\mathrm{K}_{2} \mathrm{CO}_{3}\right)$ dapat tercampur.

- Bersamaan dengan pekerjaan di atas, dibuat blanko, dimana sebagai pengganti larutan ekstraksi daging ikan dipakai $1 \mathrm{ml}$ larutan TCA 7,5\%.

- Kemudian disimpan dalam incubator dengan suhu $37^{\circ} \mathrm{C}$ selama 80 menit atau di dalam suhu kamar selama 24 jam. Pada saat tersebut terjadi penguraian ekstrak daging yang melepaskan basa-basa menguap oleh Potassium Karbonat. Basa-basa tersebut kemudian diserap oleh Asam Borat.

- Pada waktu reaksi itu terjadi, pH larutan akan meningkat dan berubah menjadi basa dan ditandai oleh warna hijau.

- Asam Borat yang mengandung basa-basa menguap segera dititrasi dengan larutan Asam Klorida encer $(0,02 \mathrm{~N} \mathrm{HCl})$.

- Titik akhir titrasi adalah pada waktu Asam Borat kembali warna merah muda atau ke tingkat $\mathrm{pH}$ awal dari larutan. Hal Ini berarti titrasi hanya ditujukan untuk pengambilan basa-basa menguap yang terikat pada Asam Borat. Kadar TVB-N dalam $100 \mathrm{~g}$ daging ikan dapat ditentukan dengan rumus berikut: TVB-N (mg N/100 gr daging) - (a-b) $\times 0,28 \times$ faktor pengenceran

Dimana :

$\mathrm{a} \quad=$ jumlah ml Asam Klorida yang dipakai mentiter larutan sampel $\mathrm{b} \quad=$ jumlah $\mathrm{ml}$ Asam Klorida yang dipakai mentiter blanko

$0,28=$ jumlah Ammonium Nitrogen yang setara dengan $1 \mathrm{ml}$ 0,02 $\mathrm{N}$ larutan Asam Klorida.

\section{Penentuan Nilai pH}

Menurut Suwetja, dkk (2007), bahwa penentuan $\mathrm{pH}$ dapat dilakukan dengan menggunakan $\mathrm{pH}$ meter, dengan urutan kerja sebagai berikut :

- Timbang sampel yang telah dirajang kecilkecil sebanyak $10 \mathrm{~g}$ dihomogenkan menggunakan mortar dengan $20 \mathrm{ml}$ aquades selama 1 menit.

- Tuangkan kedalam beker glass $10 \mathrm{ml}$, kemudian diukur pH-nya dengan menggunakan $\mathrm{pH}$ meter.

- Sebelum pH meter digunakan, harus ditera kepekaan jarum penunjuk dengan larutan buffer $\mathrm{pH} 7$.

- Besarnya pH adalah pembacaan jarum penunjuk $\mathrm{pH}$ setelah jarum skala konstan kedudukannya.

\section{Analisa Total Bakteri (Metode Sebar)}

Total bakteri dianalisa dengan menggunakan metode sebar (Ijong, 2003). Metode ini bersifat kuantitatif, dengan menghitung jumlah populasi mikroba yang ada dalam bahan pangan ikan. Mikroba yang tumbuh pada metode ini sebagian besar bersifat aerobic. Prosedur pengujiannya ialah sebagai berikut:

- Semua peralatan yang digunakan dalam analisa mikrobiologis disterilkan terlebih dahulu dengan menggunakan autocave pada suhu $121^{\circ} \mathrm{C}$, dengan tekanan 15 psi, selama 15 menit.

- Disiapkan tabung reaksi yang telah diberi kode, lalu diisi dengan $9 \mathrm{ml} \mathrm{NaCl} 0,9 \%$, kemudian disterilkan.

- Sampel ditimbang $10 \mathrm{~g}$, ditambah $10 \mathrm{ml}$ larutan $\mathrm{NaCl} \quad 0,9 \%$ kemudian diblender sampai homogen.

- Sampel ini merupakan suspense dari pengencer di atas dan dipindahkan kedalam tabung reaksi lain yang telah berisi $9 \mathrm{ml}$ $\mathrm{NaCl}$ dan diperoleh $0,9 \%$ steril pengencer $10^{-2}$. Demikian seterusnya sampai tingkat pengencer 10-3.

- Diambil NA yang telah disterilkan dan masih dalam keadaan hangat (suhu kira-kira $37-45^{\circ} \mathrm{C}$ ) secara aseptik sebanyak $15 \mathrm{ml} \mathrm{NA}$ 
dituangkan kedalam cawan petri yang telah diberi kode, lalu tunggu sampai media tersebut mengeras.

- Setelah NA mengeras, dari setiap pengenceran diambil masing-masing $1 \mathrm{ml}$ suspense dan dipindahkan ke dalam media NA yang telah di beri kode, lalu dengan menggunakan batang penyebar gelas steril, suspensi tersebut disebarkan diseluruh permukaan media secara merata. Sementara penyebaran suspense dilakukan, cawan petri diputar perlahan-lahan.

- Semua cawan petri dimasukan kedalam incubator dengan posoisi terbalik, dan diinkubasi selama 24 jam pada suhu $37^{\circ} \mathrm{C}$.

- Kemudian dihitung jumlah koloni pada masing-masing petri. Untuk mendapatkan hasil yang baik maka setiap pengencera dibuat duplo. Jumlah koloniyang dihitung pada cawan petri yaitu antara 30-300 koloni dan dalam keadaan koloni bebas.

- Sebab itu, jumlah yang diperoleh dikalikan dengan satu per tingkat pengenceran.

$$
\begin{gathered}
\text { Total Koloni }(\mathrm{cfu} / \mathrm{g})= \\
\text { Jumlah Koloni } \times \frac{1}{\text { Tingkat Pengenceran }}
\end{gathered}
$$

\section{Uji Organoleptik (SNI 2009)}

Metode uji yang dipakai yaitu uji sensori dengan menggunakan skala angka 1 sebagai nilai terendah dan angka 9 sebagai nilai tertinggi. Batas penolakan untuk ikan asap ialah 7 , artinya bila produk ini di uji memperoleh lebih kecil dari 7 maka produk tersebut dinyatakan tidak memenuhi standar mutu (ditolak).

\section{Analisa Data}

Data yang diperoleh dibedakan menjadi 2 kategori yaitu data kualitatif dan data kuantitatif. Data kualitatif dilakukan cukup dengan menghubungkan makna dari ke empat data uji yang dilakukan. Data kuantitatif adalah data dalam bentuk bilangan, tabel-tabel, dan grafik. Data untuk uji TVB-N, pH, kadar air dan organoleptik yang diperoleh, dianalisa menggunakan rumus rataan. Data dari hasil pengujian laboratorium dipaparkan secara deskriptif. Hasil pengamatan jumlah bakteri (TPC) disajikan dalam bentuk tabel. Selanjutnya hasil tersebut dikaji dan dibandingkan dengan persyaratan mutu ikan asap. Analisa data pengujian organoleptik yaitu kenampakan, bau, rasa, dan tekstur ditabulasi dan ditentukan nilai mutu ikan asap dengan mencari nilai rata-rata dari setiap panelis.

\section{HASIL DAN PEMBAHASAN}

\section{Kadar Air}

Rata-rata nilai kadar air ikan julungjulung asap yang diperoleh dari penelitian pada pasar Karombasan selama penyimpanan 21 hari pada suhu kamar dapat dilihat pada Gambar 1.

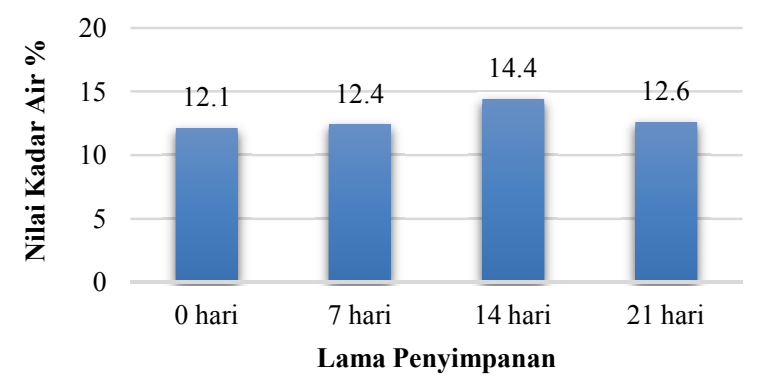

Gambar 1. Nilai Kadar Air Ikan Julung-Julung (Hemirhamphus sp.) Asap selama Penyimpanan 21 Hari.

Variasi nilai pada Gambar 1 memperlihatkan bahwa mutu ikan julung-julung asap yang diperoleh dari Pasar Karombasan pada penyimpanan 0 hari dengan menggunakan suhu ruang (A1B1) adalah 12,1 \% , pada penyimpanan 7 hari (A1B2) adalah 12,4 \%, pada penyimpanan 14 hari (A1B3) adalah 14,4 $\%$, sedangkan pada penyimpanan 21 hari (A1B4) adalah 12,6 \%. Gambar 1 juga memperlihatkan bahwa nilai kadar air sampel ikan julung-julung asap yang ada di pasar Karombasan mengalami peningkatan dari penyimpanan 0 hari sampai penyimpanan 14 hari dan terjadi penurunan pada penyimpanan 21 hari. Hal ini kemungkinan disebabkan karena pengaruh kelembaban disekitar tempat penyimpanan sampel, dimana bila kelembaban lingkungan lebih tinggi dari kelembaban sampel maka akan terjadi penyerapan air oleh sampel sehingga kadar air sampel meningkat. Sebaliknya bila kelembaban lingkungan sampel lebih rendah dari kelembaban sampel maka akan terjadi penguapan air dari sampel sehingga kadar air sampel menurun.

Winarno (1980), menyatakan bahwa kadar air suatu produk dipengaruhi oleh kelembaban nisbi udara sekelilingnya. Jika kelembaban ruang lebih tinggi, produk akan menyerap air, dan bila kelembaban ruang penyimpanan rendah produk akan menguapkan airnya (Syarief dan Halid, 1980). 
Nilai kadar air hasil penelitian menunjukan bahwa daya simpan ikan julungjulung asap atau sering disebut dengan ikan roa yang berada di pasar yang ada di Kota Manado relatif panjang. Kadar air merupakan parameter yang penting untuk menentukan kualitas ikan asap yang dihasilkan. Kadar air yang terkandung di dalam ikan asap dapat mempengaruhi daya simpan ikan asap.

Berdasarkan Standar Nasional Indonesia (SNI) menurut BSN (2009) nilai kadar air produk ikan kering maksimal 20\%. Berdasarkan Hasil penelitian yang ada bisa disimpulkan bahwa rata-rata nilai dari kadar air ikan julungjulung asap masih memenuhi syarat mutu SNI untuk ikan kering.

\section{Penentuan Derajat Keasamaan (pH)}

Rata-rata niai $\mathrm{pH}$ ikan Julung-Julung Asap yang diperoleh dari Pasar Karombasan pada penyimpanan 0 hari (A1B1) adalah 6.0, pada penyimpanan 7 hari (A1B2) adalah 6.05, pada penyimpanan 14 hari (A1B3) adalah 5.99, sedangkan pada penyimpanan 21 hari (A1B4) adalah 5.87 . Histogram nilai $\mathrm{pH}$ di pasar Karombasan pada setiap penyimpanan dapat dilihat pada pada Gambar 2.

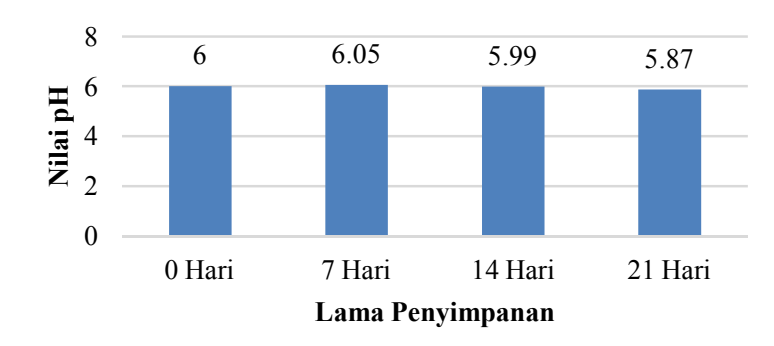

Gambar 2. Nilai pH Ikan Julung-Julung (Hemirhamphus sp.) Asap selama Penyimpanan 21 Hari.

Menurut Riyanto $d k k$ (2006), nilai $\mathrm{pH}$ dan nilai TVB-N berhubungan dengan aktivitas bakteri dan enzim yang secara alami sudah ada. Kondisi ini menyebabkan peningkatan $\mathrm{pH}$ yang mengakibatkan pembentukan ammonia, TMA, dan turunannya. Nilai $\mathrm{pH}$ merupakan salah satu indikator yang digunakan untuk menentukan tingkat kesegaran ikan. Pada proses pembusukan ikan, perubahan $\mathrm{pH}$ daging sangat besar peranannya karena berpengaruh terhadap proses autolysis dan penyerangan bakteri.

Suwetja (2013) menyatakan derajat keasaman $(\mathrm{pH})$ ikan yang masih hidup sekitar 7.0 , setelah mati akan menurun berkisar 5.8 6.2 di saat terjadi kekejangan (rigormortis).
Menurut Fardiaz (1982), pH yang baik untuk ikan yang diawetkan antara $2.0-5.5$ sedangkan $\mathrm{pH}$ antara $6.0-8.0$ merupakan media yang baik untuk pertumbuhan mikroorganisme. Nilai $\mathrm{pH}$ yang didapat dari hasil penelitian ini masih berada pada kriteria mutu yang baik yaitu berkisar $5,87-6,05$.

\section{Analisa Total Volatile Base-Nitogen (TVB-N)}

TVB-N merupakan salah satu indeks kesegaran produk perikanan. Nilai ini dapat bersifat untuk menguji tingkat mutu ikan julung-julung asap yang diambil dari Pasar Karombasan yang ada di Kota Manado, selama penyimpanan 21 hari pada suhu ruang.

Rata-rata nilai TVB-N ikan Julungjulung asap yang diperoleh dari Pasar Karombasan pada penyimpanan 0 hari (A1B1) adalah $50.82 \mathrm{mg} \mathrm{N} / 100 \mathrm{~g}$ sampel, pada penyimpanan 7 hari (A1B2) adalah $52.92 \mathrm{mg}$ $\mathrm{N} / 100 \mathrm{~g}$ sampel, pada penyimpanan 14 hari (A1B3) adalah $43.26 \mathrm{mg} \mathrm{N} / 100 \mathrm{~g}$ sampel, sedangkan untuk penyimpanan 21 hari (A1B4) adalah $60.9 \mathrm{mg} \mathrm{N} / 100 \mathrm{~g}$ sampel. Nilai TVB-N di pasar Karombasan pada setiap penyimpanan dapat dilihat pada Gambar 3.

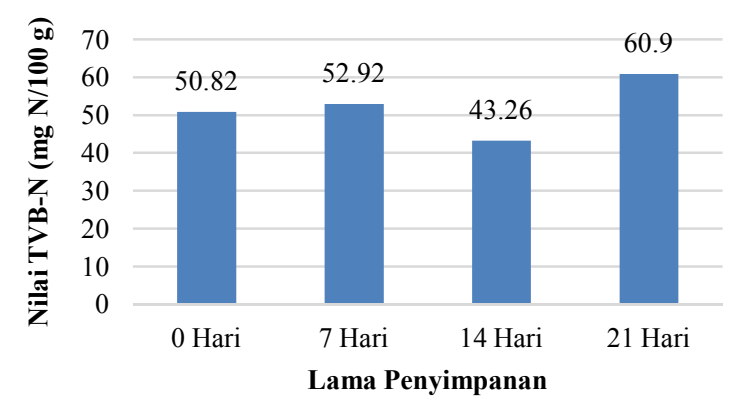

Gambar 3. Nilai TVB-N Ikan Julung-julung (Hemirhamphus sp.) Asap selama Penyimpanan 21 Hari.

Gambar 3 menunjukan bahwa nilai TVB-N ikan roa asap yang diambil di pasar Karombasan selama penyimpanan 21 hari mengalami kenaikan yaitu dari 50,82 mg N/100 g sampel menjadi $60,9 \mathrm{mg} \mathrm{N} / 100 \mathrm{~g}$ sampel. Nilai TVB-N meningkat seiring dengan peningkatan aktivitas bakteri karena salah satu hasil penguraian dari bakteri adalah senyawa yang tergolong basa-basa menguap.

Standar nilai TVB-N ikan olahan (ikan yang dikeringkan dan digarami) menurut SNI 2006 adalah 100 - $120 \mathrm{mg} \mathrm{N} / 100 \mathrm{~g}$ sampel. Dari data diatas dapat dilihat bahwa nilai TVB$\mathrm{N}$ untuk ikan roa asap yang ada diketiga pasar tradisional di kota Manado masih tergolong 
bermutu baik sampai pada penyimpanan 21 hari. TVB-N digunakan sebagai batasan yang layak dikonsumsi. Peningkatan nilai TVB-N selama penyimpanan diduga disebabkan oleh degradasi protein dan derivatnya sehingga dengan semakin lajunya proses kemunduran mutu oleh mikroba yang menghasilkan sejumlah basa-basa yang mudah menguap seperti amoniak, H2S dan histamine (James, 1978).

\section{Total Plate Count (TPC)}

Data pengamatan jumlah bakteri pada sampel ikan roa asap di ketiga pasar dengan menggunakan metode TPC pada suhu inkubasi $37^{\circ} \mathrm{C}$ selama 24 jam dapat di lihat pada Gambar 4.

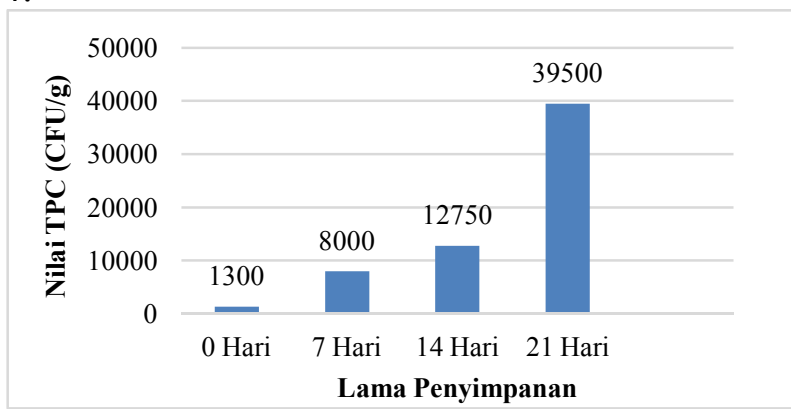

Gambar 4. Nilai TPC Ikan Julung-julung (Hemirhamphus sp.) Asap selama Penyimpanan 21 Hari.

Dari Gambar 4 tampak bahwa nilai TPC pada produk ikan julung-julung asap yang berasal dari pasar Karombasan mengalami peningkatan dari 0 hari sampai pada lama penyimpanan 21 hari. Sampel yang diambil di Pasar Karombasan pada 0 hari $1300 \mathrm{CFU} / \mathrm{g}$ menjadi $39500 \mathrm{CFU} / \mathrm{g}$. Jumlah tersebut masih berada dibawah batas maksimum nilai TPC ikan asap yang direkomendasikan oleh Badan Standar Nasional Indonesia (SNI 2725:1:2009) dimana batas maksimum nilai TPC adalah $1,0 \times 10^{5} \mathrm{koloni} /$ gram .

Mutu dari suatu produk akhir akan ditentukan oleh keadaan sanitasi hygiene dari bahan mentah, selama pengolahan hingga menjadi produk akhir (Ilyas, 1972). Tinggi atau rendahnya mikroba disebabkan oleh penanganan ikan, harus memperhatikan sanitasi dan hygiene selama pengolahan hingga produk akhir, sehingga perkembangan mikroba dapat dikontrol dan dapat mencegah terjadinya kontaminasi pada produk.

Menurut Ilyas (1983), pertumbuhan bakteri pada ikan sangat dipengaruhi oleh suhu, semakin rendahnya suhu ikan semakin lambat pertumbuhan bakteri. Menurut Moeljanto (1982) baik buruknya penanganan sangat menentukan mutu ikan sebagai bahan mentah untuk pengolahan lebih lanjut. Hal lainnya menurut Junianto (2003) bahwa penanganan ikan setelah penangkapan memegang perananan penting untuk memperoleh nilai jual ikan yang maksimal dan salah satu faktor yang dapat menentukan nilai jualnya adalah mutu dari ikan tersebut.

\section{Pengujian Organoleptik Kenampakan}

Hasil penilaian panelis terhadap nilai rata-rata organoleptik (Kenampakan) menunjukan nilai kenampakan pada Gambar 5.

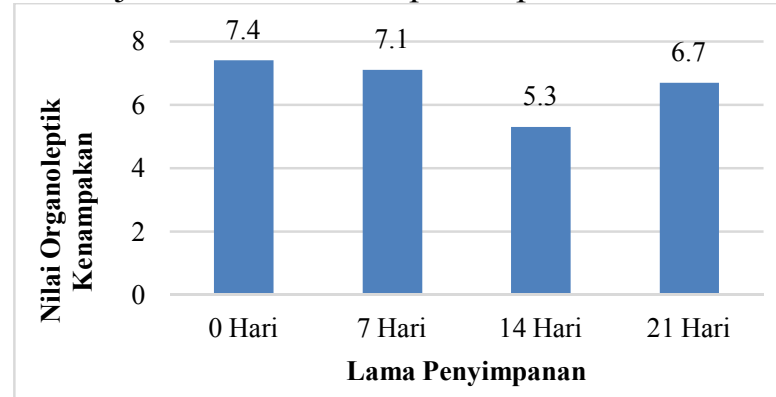

Gambar 5. Hasil Penilaian terhadap Nilai Organoleptik (Kenampakan) Ikan Julung-Julung (Hemirhamphus sp.) Asap selama Penyimpanan 21 Hari

Dari Gambar diatas dapat dilihat bahwa rata-rata nilai organoleptik kenampakan ikan Julung-Julung asap mengalami peningkatan pada penyimpanan 0 hari dengan nilai 7,4 kemudian terjadi penurunan pada penyimpanan 7 hari dengan nilai 7,1 dan pada penyimpanan 14 hari juga terjadi penurunan dengan nilai 5,3, namun pada penyimpanan 21 hari justru terjadi kenaikan dengan nilai 6,7. Kemungkinan hal ini dipengaruhi oleh lama penyimpanan. Gambar 5 juga menunjukan bahwa dari penilaian panelis, dimana semakin lama waktu penyimpanan juga mempengaruhi nilai organoleptik dari segi kenampakan. Hal penampakan produk biasanya berhubungan dengan warna, keutuhan barang, serta ada tidaknya kapang pada permukaan bahan.

Menurut Moeljanto (1992), warna yang dikendaki oleh konsumen sebagai warna ideal dari ikan hasil proses pengasapan adalah warna kuning emas kecoklatan. Hal ini disebabkan oleh adanya reaksi kimia dari persenyawaan dalam asap antara formaldehid dengan fenol yang menghasilkan lapisan dammar tiruan pada 
permukaan kulit ikan. Dari segi kenampakan produk, ada yang sebagian tampak hangus (terlalu merah kecokelatan). Hal ini dimungkinkan karena ruang pengasapan kecil, dan asap yang terlalu banyak.

Dalam penelitian ini, produk yang paling disukai pada Pasar Karombasan dengan nilai 7.4 pada penyimpanan 0 hari. Nilai organoleptik yang diperoleh masih baik, bersih, dan masih diterima panelis. Nilai persyarataan mutu ikan asap yang direkomendasikan menurut SNI yaitu minimal 7 .

\section{Bau}

Nilai rata-rata organoleptik (Bau) ikan julung-julung asap dapat dilihat pada Gambar di bawah ini.

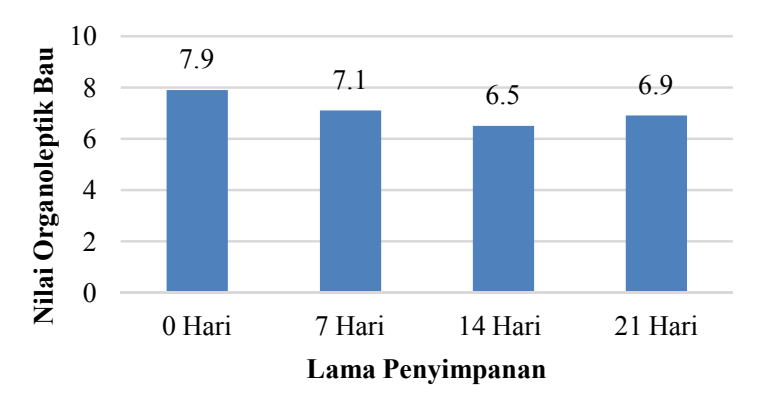

Gambar 6. Hasil Penilaian terhadap Nilai Organoleptik (Bau) Ikan JulungJulung (Hemirhamphus sp.) Asap selama Penyimpanan 21 Hari.

Pada Gambar 7 di atas panelis memberikan penilaian tertinggi pada sampel yang di ambil di Pasar Karombasan dengan nilai 7.9 pada penyimpanan 0 hari, yaitu pada produk ikan tercium bau harum asap cukup, tanpa bau tambahan mengganggu. Sedangkan sampel pada penyimpanan 14 hari mengalami penurunan dengan nilai 6.5 .

Kurangnya nilai bau tersebut diduga sebagai akibat pelepasan senyawa-senyawa lain yang tidak dikendaki yang ikut bersama-sama di dalam asap. Widiastuti (2007) menyatakan kehadiran miroorganisme pada ikan juga mengakibatkan perubahan bau. Bau tersebut timbul akibat timbulnya amoniak (NH3) pada degradasi protein dan gas $\mathrm{H} 2 \mathrm{~S}$ pada degradasi protein yang mengandung unsur sulfur oleh bakteri pembentuk gas H2S. Berdasarkan Gambar diatas dapat dilihat bahwa penilaian bau yang diterima panelis dan disukai terdapat pada penyimpanan 0 hari.
Rasa

Rata-rata nilai organoleptik (Rasa) ikan julung-julung asap yang diperoleh pada penyimpanan 0 hari, 7 hari, 14 hari, dan 21 hari tidak berbeda jauh, seperti yang ada pada Gambar 7 di bawah ini.

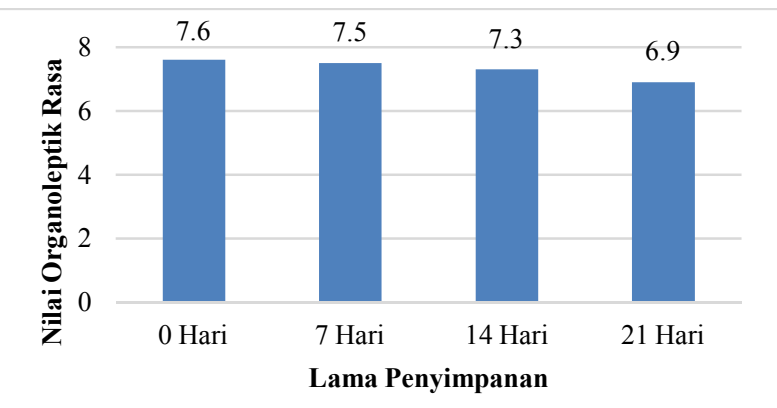

Gambar 7. Hasil Penilaian terhadap Nilai Organoleptik (Rasa) Ikan JulungJulung (Hemirhamphus sp.) Asap selama Penyimpanan 21 Hari.

Panelis memberikan nilai 7.6 pada penyimpanan 0 hari dan nilai 6.9 pada penyimpanan 21 hari, bisa di tarik kesimpulan bahwa kesukaan panelis pada nilai organoleptik (Rasa) dipengaruhi lama penyimpanan.

Menurut Wibowo (1996), kriteria mutu organoleptik untuk rasa ikan asap adalah enak, rasa asap terasa lembut sampai tajam tanpa rasa getir atau pahit, dan tidak berasa tengik. Adanya nilai kesukaan dan hasil ranking menunjukan bahwa rasa dengan nilai terendah adalah rasa yang tidak disukai dan sebaliknya untuk nilai tertinggi merupakan respons dari rasa yang disukai. Adapun dalam pemanfaatannya, ikan julung-julung asap memiliki rasa yang enak namun hanya dapat dijadikan sebagai bahan penyedap dan tambahan pada makanan.

Berdasarkan penilaian panelis terhadap nilai cita rasa terbaik adalah 7.6 pada penyimpanan 0 hari. Hal ini menunjukan bahwa produk dengan penyimpanan 0 hari, nilai organoleptik dari segi rasa disukai panelis. Nilai persyaratan mutu ikan asap yang direkomendasikan menurut SNI yaitu minimal 7.

\section{Tekstur}

Produk ikan julung-julung asap yang biasa dipasarkan memiliki tekstur yang keras, sehingga melalui penelitian ini menunjukan adanya keterkaitan panelis terhadap produk. 


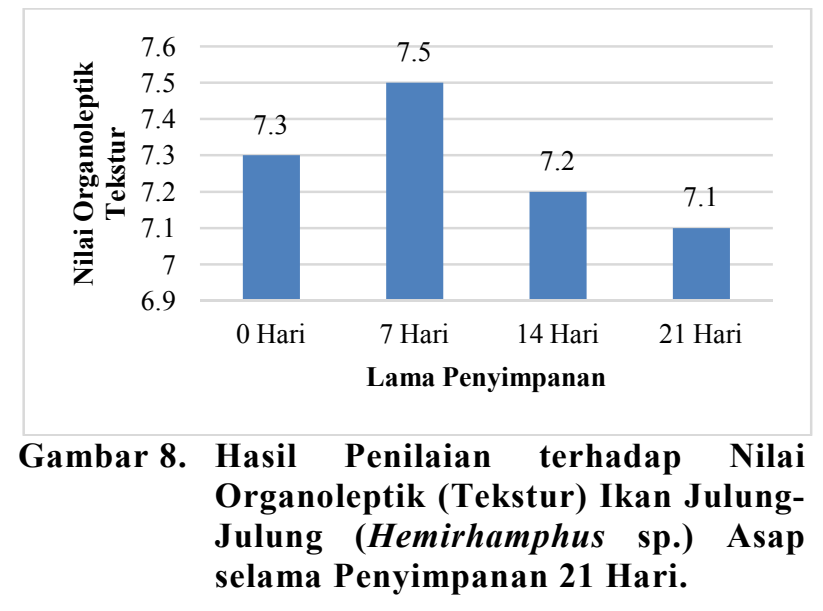

Nilai tingkat kesukaan panelis terhadap nilai organoleptik (Tekstur) tertinggi adalah 7.5 pada penyimpanan 7 hari. Berdasarkan Gambar diatas nilai tertinggi yang diberikan panelis berhubungan dengan kadar air dari bahan tersebut, dimana nilai kadar air untuk pasar Karombasan rendah yaitu 12.4 pada penyimpanan 7 hari. Nilai tekstur suatu produk dipengaruhi juga oleh kadar air daging ikan yang segar dan perendaman dalam air garam dapat mengurangi kadar air, menghambat pertumbuhan mikroba, sehingga menyebabkan daging ikan lebih kompak, tekstur lebih baik dan disukai panelis.

Wibowo (2000) menyatakan bahwa keadaan tekstur bahan merupakan suatu sifat dari bahan pangan yang paling penting. Produk yang memiliki tekstur yang paling baik memiliki mutu yang baik. Adapun kadar air dapat mempengaruhi tekstur dari suatu produk (Sakidja, 1989). Dari hasil penelitian ini, dengan jumlah kadar air yang rendah yaitu 12.4 pada penyimpanan 7 hari berhubungan dengan kesukaan panelis pada tekstur daging ikan julung-julung asap dengan nilai yang diperoleh yaitu 7.5 pada penyimpanan 7 hari. Karena semakin rendah nilai kadar air maka nilai teksturnya semakin tinggi, begitupun sebaliknya. Nilai persyaratan mutu ikan asap yang direkomendasikan menurut SNI yaitu minimal 7.

\section{KESIMPULAN}

Berdasarkan hasil penelitian yang di lakukan, maka bisa di tarik kesimpulan sebagai berikut :

- Berdasarkan hasil penelitian mutu ikan julung-julung (Hemirhamphus sp.) asap maka diperoleh nilai kadar air dan $\mathrm{pH}$, dari sampel yang diambil di pasar Karombasan.
Berdasarkan hasil penelitian yang ada bisa disimpulkan bahwa rata-rata nilai dari kadar air ikan julung-julung (Hemirhamphus sp.) asap masih memenuhi syarat mutu SNI untuk ikan kering dengan masa simpan yang panjang. Dan untuk nilai $\mathrm{pH}$, jumlah nilai yang diperoleh masih berada pada kriteria mutu yang baik.

- Mutu ikan julung-julung asap berdasarkan nilai TVB-N dari penyimpanan 0 hari, 7 hari, 14 hari dan 21 hari, masih masuk dalam standar nilai TVB-N ikan olahan. Berdasarkan nilai yang di dapat pada penelitian ini menunjukan bahwa produk ikan ini masih layak untuk dikonsumsi.

- Mutu ikan julung-julung asap berdasarkan nilai TPC dari hasil penelitian yang ada, produk ikan julung-julung asap yang disimpan dari penyimpanan 0 hari sampai penyimpanan 21 hari masih memenuhi standar mutu ikan asap yang di rekomendasikan oleh Badan Standar Nasional Indonesia (SNI 2725:1:2009).

- Berdasarkan kriteria mutu dan penilaian organoleptik, ikan julung-julung asap untuk kenampakan, bau, rasa dan tekstur belum mengalami kemunduran mutu dan masih bisa diterima.

\section{DAFTAR PUSTAKA}

Abu Faiz. 2008. Pengasapan Ikan. Jakarta : PT Bumi Aksara.

Adawyah, Rabiatul. 2007. Pengolahan dan Pengawetan Ikan. Jakarta : PT Bumi Aksara.

Dinas Kelautan dan Perikanan. 2008. Produksi Perikanan Laut Kabupaten/Kota. Dinas Kelautan dan Perikanan Kabupaten Banggai. Propinsi Sulawesi Tengah.

Berhimpon, S., Ijong, F. G., Moniharapon, T., 2002. Penuntun Praktikum Penilaian Indera. Laboratorium Penanganan dan Pengolahan Hasil Perikanan. FPIK. UNSRAT.

Badan Standarisasi Nasional. 2006. Standar Nasional Indonesia 01-2346-2006. Uji Organoleptik Ikan Segar. Jakarta; Badan Standarisasi Nasional Indonesia.

Dwidjoseputro, D. 2005. Dasar-dasar Mikrobiologi. Djambatan : Jakarta

Fardiaz, S., 1982. "Mikrobiologi Pangan”. Jilid 1. Jurusan Ilmu dan Teknologi Perikanan. Jakarta.

Fardiaz, S. 1992. Mikrobiologi Pangan 1. Jakarta: Gramedia Pustaka Utama.

Ilyas, S, 1983. "Teknologi Refrigerasi Hasil Perikanan". Jilid 1. Penerbit Liberty. Yogyakarta.

Juniarto. 2003. Teknik Penanganan Ikan. Jakarta : Penebar Swadaya. 
Kose, S. 2003. An Investigation of Quality In Anchovy (Engraulis ancarasicolus). Stored at Different Temperaturs. Turk J Vet Anim Sci 28 ; 575-582.

Marassebesy, Ismael. 2011. Aplikasi Asap Cair dalam Pengolahan Ikan Tongkol (Eutynnus a ffinis) Asap (Aplied of Liquid Smoked in Little Tuna Fish (Eutynnus affinis) of Smoke Processing).

Moeljanto, R. 1982. Pengasapan dan Fermentasi Ikan. Cetakan ke II. PT. Penebar Swadaya.

Moeljanto, 1992. Pengawetan dan Pengolahan Hasil Perikanan. Penebar Swadaya, Jakarta.

Murniyati, A. S dan Sunarman., 2000. Pendinginan, Pembekuan dan Pengawetan Ikan. Yogyakarta.

Nelson, J., 1984. Fishes of The World. 2nd. Ed. John Wiley, New York.

Pudjirahaju, A., 1999. Penilaian Kualitas atau Mutu Makanan. Departemen Pendidikan dan Kebudayaan Fakultas Kedokteran, Universitas Brawijaya, Malang.

Pujilestari, 2008. Ikan Asap. http : //www.ITS-Research12268 -

Reppie, E. and A. Luasunaung. 2001. The status of roundscad net (talang) in Pahepa Island, Sangihe Talaud, North Sulawesi (181-186). Proceedings of the 4 th JSPS International Seminar on Fisheries in Tropical Area. Sustainable Fisheries in Asia in the New Millenium. 21-25

Saanin, H. 1984. Taksonomi dan Kunci Identifikasi Ikan. Jilid I dan II. Bina Cipta. Bogor.

Sakidja,1989. Kimia Pangan. Direktorat Pendidikan dan Kebudayaan Direktorat Jendral Pendidikan Tinggi. Jakarta.

Sandjaja, B. 1992. Isolasi dan Identifikasi Mikrobakteria. Jakarta: Widya Medika.

Saparinto, Cahyo. 2010. Usaha Ikan Konsumsi di Lahan 100 m2. Jakarta: Penebar Swadaya.

Sasmito, Bambang Budi. 2006. Dasar - dasar Pengawetan Bahan Pangan. Universitas Brawijaya. Malang.
(SNI) Standard Nasional Indonesia. 2009. Ikan Asap Bagian 1. Spesifikasi SNI 27 25.1:2009. Badan Standarisasi Indonesia.

Sudarmadji, S., B. Haryono dan Suhardi. 1989. Prosedur Analisa Untuk Bahan Makanan dan Pertanian. Penerbit Liberty. Yogyakarta.

Sudjana, N dan A. Kusuma. 2004. Proposal Penelitian di Perguruan Tinggi. Sinar Baru Algensindo. Bandung.

Susatyo, 2004. Kajian Beberapa Aspek Pengolahan Ikan Secara Tradisional dalam Upaya Peningkatan Mutu Produk Perikanan di Kabupaten Jepara. http : //www.eprints.undip.ac.id-jurnal ikan asap.pdf

Suwetja, I. K. 1993. Metode Penentuan Mutu Ikan. Jilid I. Penentuan Kesegaran. Fakultas Perikanan dan Ilmu Kelautan Universitas Sam Ratulangi Manado.

. 2007. Biokimia Hasil Perikanan. Jilid

III. Rigormortis, TMAO, dan ATP. Fakultas Perikanan dan Ilmu Kelautan. Universitas Sam Ratulangi. Manado.

2013. Indeks Mutu Kesegaran Ikan Berkandungan Hasil -Hasil Penelitian. Edisi Pertama. Bayumedia Publishing. Malang.

Tadanugi, F. A. 2004. Kombinasi Pelepah, Sabut Dan Tempurung Kelapa Sebagai Bahan Bakar Alternatif Untuk Julung - julung (Hemiramphus sp.) Asap. Skripsi. Fakultas Perikanan Dan Ilmu Kelautan. Universitas Sam Ratulangi. Manado.

Wibowo, S. 1996. Industri Pemindangan Ikan. Penebar Swadya.

Wibowo, S. 2000. Industri Pengasapan Ikan. Penebar Swadaya. Jakarta.

Widiastuti, I.M. 2007. Sanitasi dan Mutu Kesegaran Ikan Konsumsi pada Pasar Tradisional Di Kotamadya Palu. Jurnal. Agroland 14 (1):77-81 ISSN: 0854-641X.

Winarno, F.G., Fardiaz, S. 1980. Pengantar Teknologi Pangan. Penerbit PT. Gramedia. Jakarta.

Winarno, F. G. 1993. Pangan, Gizi, Teknologi dan Konsumen. Gramedia. Jakarta. 